\title{
Chemical Behavior and Reaction Kinetics of Sulfur and Nitrogen Half- Mustard and Iprit Carbonate Analogues
}

\author{
Fabio Aricò, ${ }^{\dagger}$ Serena Evaristo, ${ }^{\dagger}$ and Pietro Tundo*, ${ }^{\dagger}$ \\ ${ }^{\dagger}$ Department of Environmental Science, Informatics and Statistics, University Ca’ Foscari of Venice, 2137 Dorsoduro, 30123 Venezia, \\ Italy
}

Supporting Information


ABSTRACT: Sulfur and nitrogen mustards are very toxic, yet versatile organic molecules with numerous applications. Herein, we report on a synthesis of a new class of green compounds, i.e., half-mustard and iprit carbonates, that result in new, unexplored, and safe molecules. Their chemical behavior with several nucleophiles and their reaction kinetics have been investigated.

KEYWORDS: Dimethyl carbonate, Mustard compound, Green chemistry, Anchimeric effect, Kinetics

\section{INTRODUCTION}

Nitrogen and sulfur mustards, namely, bis- $N, N$-(2-chloroethyl)ethylamine and bis-(2-chloroethyl)sulfide, are infamously known to be cytotoxic vesicant substances widely used as chemical weapons during World War I (Figure 1). ${ }^{1-3}$ However,

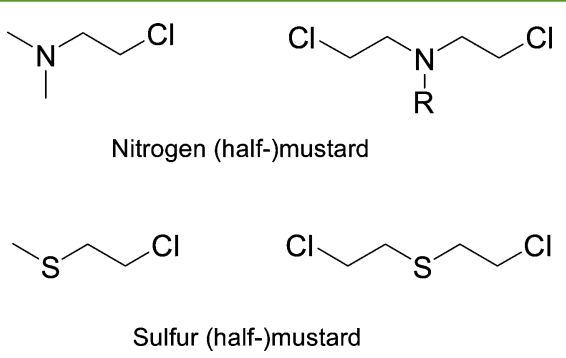

Figure 1. Sulfur and nitrogen mustards.

their acute toxicity, deadly on the battlefield, is also what renders them a class of versatile and interesting compounds extensively exploited in inorganic ${ }^{4-7}$ and organic chemistry. ${ }^{8-14}$ It is, in fact, well known that the toxicity of mustard compounds is strictly related to their high reactivity.

Sulfur and nitrogen mustards, as well as their monofunctional analogues half-mustards, i.e., 2-chloroethyl methyl sulfides and 2-chloroethyl dimethylamine (Figure 1), readily eliminates a chloride ion by intramolecular nucleophilic substitution promoted by the sulfur or nitrogen anchimeric effect. The resulting cyclic episulfonium/aziridinium ion intermediates are highly reactive toward nucleophilic substitution. ${ }^{15}$

Furthermore, nitrogen mustard bis- $N, N$-(2-chloroethyl)ethylamine and a number of its derivatives are of vivid interest because they are extensively used in various cancer treatments. ${ }^{16-24}$

We already reported several examples where substituting a chlorine atom with a carbonate moiety via dialkyl carbonate (DAC) chemistry resulted in new green synthetic pathways with various applications, i.e., synthesis of linear and cyclic carbamates, selective mono-C-methylation of $\mathrm{CH}_{2}$-acidic compounds such as arylacetonitriles that are intermediates of several anti-inflammatory drugs. ${ }^{25-27}$

Dialkyl carbonate (DACs) and in particular DMC are, in fact, well recognized green reagents and solvents for innovative synthetic pathways and industrial processes, ${ }^{28-30}$ i.e., preparation of cyclic compounds and varnish formulation. ${ }^{31-36}$

$\mathrm{DMC}$, nowadays mainly synthesized by $\mathrm{CO}_{2}$ insertion into epoxides, ${ }^{29,30}$ has shown over the last 20 years a surprising and high selectivity with different monodentate and bidentate nucleophiles. ${ }^{37-42}$ The reactivity of the two electrophilic centers of DMC can be modulated according to the hardsoft acid-base (HSAB) theory. DMC acts as a methoxycarbonylation agent via a $\mathrm{B}_{\mathrm{Ac}} 2$ mechanism at reflux temperature $(T=$

Received: June 12, 2013

Revised: July 11, 2013

Published: July 16, 2013 
$90{ }^{\circ} \mathrm{C}$ ) and as a methylating agent, via a $\mathrm{B}_{\mathrm{Al}} 2$ mechanism, at higher temperature $\left(T>150{ }^{\circ} \mathrm{C}\right)$. Both reactions give as byproduct only methanol and eventually $\mathrm{CO}_{2}$.

Recently, we have reported the synthesis of sulfur and nitrogen half-mustard carbonate analogues via DMC chemistry. Investigations conducted on the reactivity of these novel compounds demonstrated that the replacement of a chlorine atom with a carbonate moiety via DMC chemistry resulted in harmless compounds with interesting reactivity. ${ }^{43}$

In this work, in order to expand our knowledge of this class of compounds, we report on the synthesis and chemical behavior of novel half-mustard carbonates 1-4 (Scheme 1) incorporating a propyl or butyl alkyl chain and of double functionalized iprit carbonates 11-13 (Scheme 3).

The reaction mechanisms of the mustard carbonate analogues with a simple nucleophile have also been studied. Following the previously reported data, ${ }^{43}$ we have further investigated and compared the reaction kinetics of half-mustard carbonates in order to determine their related activation energy values.

\section{EXPERIMENTAL SECTION}

General Procedure for Mustard Carbonates 1-4 and 11-13. In a typical experiment, the starting alcohol ( 1 mol equiv), DMC (10 mol equiv), and potassium carbonate ( 1 mol equiv) were placed into a round-bottomed flask equipped with a reflux condenser. While being stirred magnetically, the mixture was heated at reflux temperature for $24 \mathrm{~h}$. The reaction mixture was then filtered, and the solvent was evaporated under vacuum.

3-(N,N-Dimethylamino)propyl Methyl Carbonate 1. The pure compound was obtained by distillation under vacuum; bp $110{ }^{\circ} \mathrm{C}$ (0.05 bar). Colorless liquid; yield 54\%. GC-MS: calcd for $\mathrm{C}_{7} \mathrm{H}_{15} \mathrm{NO}_{3}$ 160.20; found 160.20. ${ }^{1} \mathrm{H}$ NMR (400 $\mathrm{MHz}, \mathrm{CDCl}_{3}$ ): $\delta=1.86-1.77$ $(\mathrm{m}, 2 \mathrm{H}), 2.20(\mathrm{~s}, 6 \mathrm{H}), 2.33(\mathrm{t}, J=7.2 \mathrm{~Hz}, 2 \mathrm{H}), 3.74(\mathrm{~s}, 3 \mathrm{H}), 4.16(\mathrm{t}, J$ $=6.8 \mathrm{~Hz}, 2 \mathrm{H}) \mathrm{ppm} .{ }^{13} \mathrm{C} \mathrm{NMR}\left(400 \mathrm{MHz}, \mathrm{CDCl}_{3}\right): \delta=155.7,66.4$, 55.8, 54.5, 45.3, $26.8 \mathrm{ppm}$.

3-(Methylthio)propyl Methyl Carbonate 2. Colorless liquid; yield 73\%. GC-MS: calcd for $\mathrm{C}_{6} \mathrm{H}_{12} \mathrm{O}_{3} \mathrm{~S}$ 164.22; found 164.10. ${ }^{1} \mathrm{H}$ NMR $\left(400 \mathrm{MHz}, \mathrm{CDCl}_{3}\right): \delta=1.99-1.90(\mathrm{~m}, 2 \mathrm{H}), 2.09(\mathrm{~s}, 3 \mathrm{H}), 2.56(\mathrm{t}, J=$ $7.2 \mathrm{~Hz}, 2 \mathrm{H}), 3.77(\mathrm{~s}, 3 \mathrm{H}), 4.23(\mathrm{t}, J=6.4 \mathrm{~Hz}, 2 \mathrm{H}) \mathrm{ppm} .{ }^{13} \mathrm{C}$ NMR $\left(400 \mathrm{MHz}, \mathrm{CDCl}_{3}\right): \delta=155.6,66.5,54.6,30.2,28.1,15.4 \mathrm{ppm}$.

4-(Methylthio)butyl Methyl Carbonate 3. Colorless liquid; yield 75\%. GC-MS: calcd for $\mathrm{C}_{7} \mathrm{H}_{14} \mathrm{O}_{3} \mathrm{~S} 178.25$; found 178.10. ${ }^{1} \mathrm{H}$ NMR $\left(400 \mathrm{MHz}, \mathrm{CDCl}_{3}\right): \delta=1.73-1.64(\mathrm{~m}, 2 \mathrm{H}), 1.82-1.74(\mathrm{~m}, 2 \mathrm{H}), 2.06$ $(\mathrm{s}, 3 \mathrm{H}), 2.51(\mathrm{t}, J=7.2 \mathrm{~Hz}, 2 \mathrm{H}), 3.77(\mathrm{~s}, 3 \mathrm{H}), 4.16(\mathrm{t}, J=6.4 \mathrm{~Hz}, 2 \mathrm{H})$ ppm. ${ }^{13} \mathrm{C}$ NMR $\left(400 \mathrm{MHz}, \mathrm{CDCl}_{3}\right): \delta=155.8,67.6,54.7,33.7,27.7$, 25.2, $15.4 \mathrm{ppm}$.

$\mathrm{N}, \mathrm{N}$-Dimethylpyrrolidinium Methyl Carbonate 4. The reaction mixture was filtered, and the solvent was evaporated. A sample of the pure compound was isolated in $90 \%$ yield as yellowish crystals. Analyses of the sample was consistent with the data reported in the literature. ${ }^{44}$

Bis-N,N-[(2-methylcarbonate)ethyl] Methylamine 11. Yellow liquid; yield 99\%. GC-MS: calcd for $\mathrm{C}_{9} \mathrm{H}_{17} \mathrm{NO}_{6}$ 235.23; found 235.20. ${ }^{1} \mathrm{H}$ NMR $\left(400 \mathrm{MHz}, \mathrm{CDCl}_{3}\right): \delta=2.37(\mathrm{~s}, 3 \mathrm{H}), 2.76(\mathrm{t}, J=6.0$ $\mathrm{Hz}, 4 \mathrm{H}), 3.76(\mathrm{~s}, 6 \mathrm{H}), 4.23(\mathrm{t}, J=6.0 \mathrm{~Hz}, 4 \mathrm{H}) \mathrm{ppm} .{ }^{13} \mathrm{C}$ NMR $(400$ $\left.\mathrm{MHz}, \mathrm{CDCl}_{3}\right): \delta=155.6,65.4,55.7,54.6,42.6 \mathrm{ppm}$.

Bis- $\mathrm{N}, \mathrm{N}$-[(2-ethylcarbonate)ethyl] Methylamine 12. Yellow liquid; yield 78\%. GC-MS: calcd for $\mathrm{C}_{11} \mathrm{H}_{21} \mathrm{NO}_{6} 263.29$; found $263.20 .{ }^{1} \mathrm{H}$ NMR (400 MHz, CDCl $): \delta=1.26(\mathrm{t}, J=6.8 \mathrm{~Hz}, 6 \mathrm{H}), 2.33(\mathrm{~s}, 3 \mathrm{H})$, $2.73(\mathrm{t}, J=6.4 \mathrm{~Hz}, 4 \mathrm{H}), 4.21-4.11(\mathrm{~m}, 8 \mathrm{H}) \mathrm{ppm} .{ }^{13} \mathrm{C} \mathrm{NMR}(400$ $\left.\mathrm{MHz}, \mathrm{CDCl}_{3}\right): \delta=155.5,65.5,64.0,56.0,42.5,14.5 \mathrm{ppm}$.

Bis-(2-methylcarbonate)ethyl Sulfide 13. Yellow liquid; yield 99\%. GC-MS: calcd for $\mathrm{C}_{8} \mathrm{H}_{14} \mathrm{O}_{6} \mathrm{~S}$ 238.26; found $221.00\left(\mathrm{M}^{+}-\mathrm{CH}_{3}\right) .{ }^{1} \mathrm{H}$ NMR $\left(400 \mathrm{MHz}, \mathrm{CDCl}_{3}\right): \delta=2.77(\mathrm{t}, J=7.2 \mathrm{~Hz}, 4 \mathrm{H}), 3.73(\mathrm{~s}, 6 \mathrm{H})$, $4.23(\mathrm{t}, J=7.2 \mathrm{~Hz}, 4 \mathrm{H}) \mathrm{ppm} .{ }^{13} \mathrm{C} \mathrm{NMR}\left(400 \mathrm{MHz}, \mathrm{CDCl}_{3}\right): \delta=$ $150.1,61.3,49.5,25.2 \mathrm{ppm}$.
Reaction of Carbonates with Nucleophiles. In a typical experiment, a mixture of the selected carbonate $(1 \mathrm{~mol}$ equiv) and the nucleophile ( $1 \mathrm{~mol}$ equiv) in acetonitrile $(100 \mathrm{~mL})$ was placed into an autoclave and heated at $180{ }^{\circ} \mathrm{C}$ while stirring. The progress of the reaction was monitored by GC-MS. After disappearance of the starting nucleophile, the reaction was stopped, and the mixture cooled to room temperature. Then, the solvent was evaporated from the clear solution.

N,N-Dimethyl-3-phenoxypropanamine 6. The resulting oil was dissolved in diethyl ether and washed three times with $200 \mathrm{~mL}$ of $\mathrm{NaOH} 10 \%$ aqueous solution. The organic phase was separated, dried with $\mathrm{MgSO}_{4}$, and the solvent evaporated. The pure compound was isolated in $84 \%$ yield $(1.6 \mathrm{~g}, 8.9 \mathrm{mmol})$ as a yellowish liquid. GC-MS: calcd for $\mathrm{C}_{11} \mathrm{H}_{17} \mathrm{NO}$ 179.26; found 179.20. ${ }^{1} \mathrm{H}$ NMR (400 MHz, $\left.\mathrm{CDCl}_{3}\right): \delta=2.05-1.95(\mathrm{~m}, 2 \mathrm{H}), 2.29(\mathrm{~s}, 6 \mathrm{H}), 2.51(\mathrm{t}, J=7.2 \mathrm{~Hz}$, $2 \mathrm{H}), 4.01(\mathrm{t}, J=6.8 \mathrm{~Hz}, 2 \mathrm{H}), 6.95-6.88(\mathrm{~m}, 3 \mathrm{H}), 7.30-7.23(\mathrm{~m}, 2 \mathrm{H})$ ppm. ${ }^{13} \mathrm{C}$ NMR $\left(400 \mathrm{MHz}, \mathrm{CDCl}_{3}\right): \delta=158.9,129.4,120.5,114.5$, $66.0,56.4,45.5,27.6 \mathrm{ppm}$.

Methyl (4-Phenoxybutyl)sulfane 9. The pure compound was obtained by extraction with dichloromethane/ $\mathrm{NaOH} 10 \%$ aqueous solution. The organic phase was separated, dried with $\mathrm{MgSO}_{4}$, and the solvent evaporated. The compound was isolated in $60 \%$ yield $(165.0$ $\mathrm{mg}, 0.8 \mathrm{mmol})$ as a yellow oil. GC-MS calcd for $\mathrm{C}_{11} \mathrm{H}_{16} \mathrm{OS} 196.31$; found 196.10. ${ }^{1} \mathrm{H}$ NMR (400 MHz, $\left.\mathrm{CDCl}_{3}\right): \delta=1.84-1.75(\mathrm{~m}, 2 \mathrm{H})$, $1.94-1.85(\mathrm{~m}, 2 \mathrm{H}), 2.11(\mathrm{~s}, 3 \mathrm{H}), 2.57(\mathrm{t}, J=7.2 \mathrm{~Hz}, 2 \mathrm{H}), 3.98(\mathrm{t}, J=$ $6.0 \mathrm{~Hz}, 2 \mathrm{H}), 6.96-6.87(\mathrm{~m}, 3 \mathrm{H}), 7.31-7.24(\mathrm{~m}, 2 \mathrm{H}) \mathrm{ppm} .{ }^{13} \mathrm{C}$ NMR $\left(400 \mathrm{MHz}, \mathrm{CDCl}_{3}\right): \delta=159.0,129.5,120.3,114.2,67.5,34.0,28.5$, 26.0, $15.5 \mathrm{ppm}$.

$\mathrm{N}, \mathrm{N}$-Dimethyl-4-cyano-4-(phenylsulfonyl)pentanamine 10 . The pure compound was obtained by column chromatography on silica gel using hexane/ethyl acetate (7:3) as elution mixture to recover the desired product in $30 \%$ yield $(119.0 \mathrm{mg}, 0.4 \mathrm{mmol})$ as a yellow oil. GC-MS calcd for $\mathrm{C}_{13} \mathrm{H}_{17} \mathrm{NO}_{2} \mathrm{~S}_{2}$ 283.41; found 283.10. ${ }^{1} \mathrm{H}$ NMR (400 $\left.\mathrm{MHz}, \mathrm{CDCl}_{3}\right): \delta=1.79-1.56(\mathrm{~m}, 4 \mathrm{H}), 2.00-1.87(\mathrm{~m}, 1 \mathrm{H}), 2.08(\mathrm{~s}$, $3 \mathrm{H}), 2.27-2.16(\mathrm{~m}, 1 \mathrm{H}), 2.50(\mathrm{t}, J=6.0 \mathrm{~Hz}, 2 \mathrm{H}), 3.94-3.89(\mathrm{~m}, 1 \mathrm{H})$, 7.69-7.62 (m, 2H), 7.81-7.74 (m, 1H), 8.04-7.99 (m, 2H) ppm. ${ }^{13} \mathrm{C}$ NMR $\left(400 \mathrm{MHz}, \mathrm{CDCl}_{3}\right): \delta=135.6,135.3,129.7,129.6,113.9,57.5$, 33.5, 28.1, 26.3, 25.7, $15.5 \mathrm{ppm}$.

$\mathrm{N}, \mathrm{N}$-Bis-(2-phenoxyethyl) Methylamine 14 . The pure compound was obtained by column chromatography on silica gel using as the elution mixture hexane/ethyl acetate (7:3) to recover the desired product in $80 \%$ yield $(408.0 \mathrm{mg}, 1.5 \mathrm{mmol}$ ) as a yellow oil. GC-MS calcd for $\mathrm{C}_{17} \mathrm{H}_{21} \mathrm{NO}_{2}$ 271.35; found 271.10. ${ }^{1} \mathrm{H}$ NMR $(400 \mathrm{MHz}$, $\left.\mathrm{CDCl}_{3}\right): \delta=2.52(\mathrm{~s}, 3 \mathrm{H}), 3.00(\mathrm{t}, J=5.6 \mathrm{~Hz}, 4 \mathrm{H}), 4.14(\mathrm{t}, J=5.6 \mathrm{~Hz}$, $4 \mathrm{H}), 6.93-6.87(\mathrm{~m}, 4 \mathrm{H}), 6.98-6.94(\mathrm{~m}, 2 \mathrm{H}), 7.31-7.24(\mathrm{~m}, 4 \mathrm{H})$ ppm. ${ }^{13} \mathrm{C}$ NMR (400 MHz, $\mathrm{CDCl}_{3}$ ): $\delta=159.1,129.8,121.1,115.0$, $66.3,57.0,43.9 \mathrm{ppm}$.

N-Methyl-4-cyano-4-phenylsulfonyl Piperidine 17. The pure compound was obtained by column chromatography on silica gel using as the elution mixture methanol/hexane $(7: 3)$ to recover the desired product in $60 \%$ yield $(256.0 \mathrm{mg}, 1.0 \mathrm{mmol})$ as a yellow oil. GC-MS calcd for $\mathrm{C}_{13} \mathrm{H}_{16} \mathrm{~N}_{2} \mathrm{O}_{2} \mathrm{~S}$ 264.34; found 264.10. ${ }^{1} \mathrm{H}$ NMR (400 $\left.\mathrm{MHz}, \mathrm{CDCl}_{3}\right): \delta=2.05-1.98(\mathrm{~m}, 2 \mathrm{H}), 2.34-2.14(\mathrm{~m}, 7 \mathrm{H}), 3.02-$ $2.93(\mathrm{~m}, 2 \mathrm{H}), 7.66-7.58(\mathrm{~m}, 2 \mathrm{H}), 7.79-7.71(\mathrm{~m}, 1 \mathrm{H}), 8.01-7.95(\mathrm{~m}$, $2 \mathrm{H}) \mathrm{ppm} .{ }^{13} \mathrm{C} \mathrm{NMR}\left(400 \mathrm{MHz}, \mathrm{CDCl}_{3}\right): \delta=135.6,133.8,131.0$, 129.7, 116.4, 62.6, 51.6, 45.8, $29.1 \mathrm{ppm}$.

Kinetic Studies. Calibration curves and kinetic studies related to the reaction of carbonates 1,18 , and 19 with phenol are reported in detail in the Supporting Information.

\section{RESULTS AND DISCUSSION}

Nitrogen and sulfur half-mustard carbonates $[(N, N$ dimethylamino)propyl methyl carbonate $\mathbf{1}$ and (methylthio)alkyl methyl carbonates (2 and 3$)$ ] have been synthesized in good to high yields $(54-75 \%)$ by reacting the commercially available alcohol with $\mathrm{DMC}$ using the $\mathrm{B}_{\mathrm{Ac}} 2$ mechanism in the presence of potassium carbonate (Scheme 1). The related carbonates have been isolated as pure compounds by vacuum distillation. It should be mentioned that similar to the 
Scheme 1. Sulfur and Nitrogen Half-Mustards Carbonates 1-4

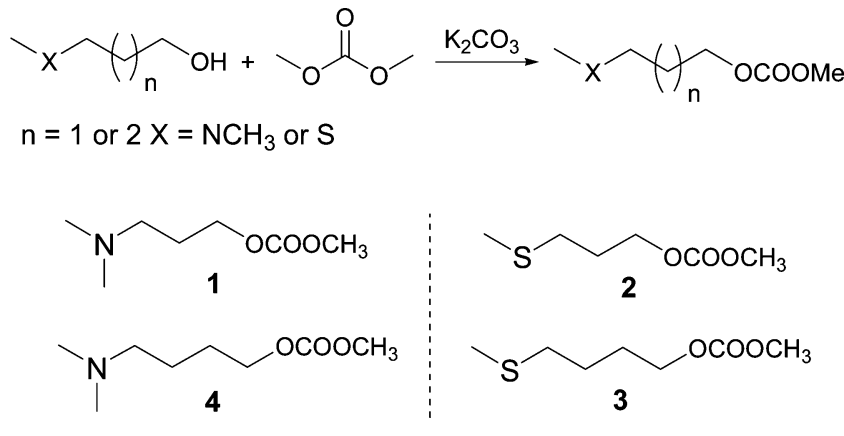

Scheme 2. Reaction Mechanism of Sulfur and Nitrogen HalfMustard Carbonates 1-4

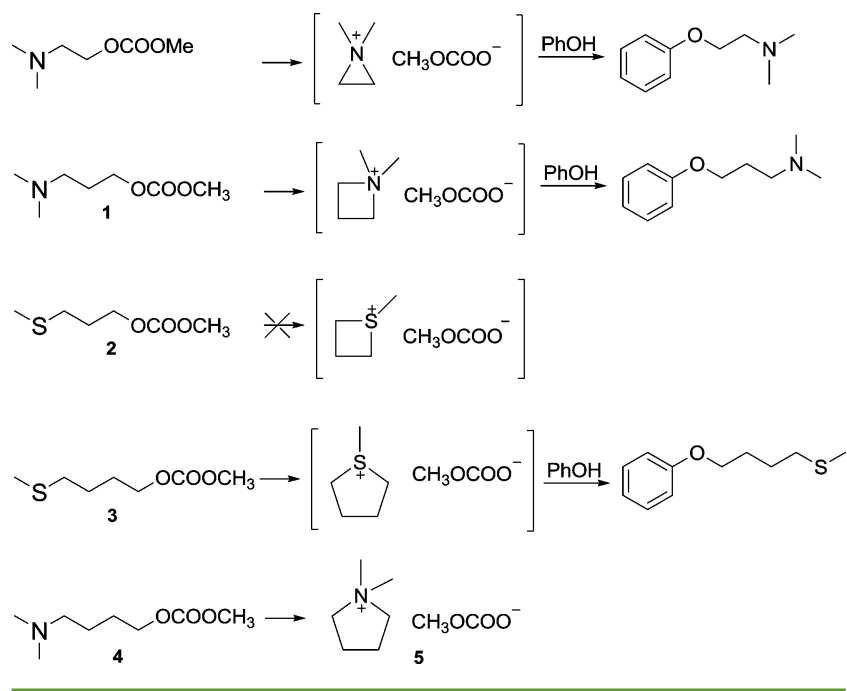

previously reported half-mustard carbonates, ${ }^{43}$ these compounds resulted new stable molecules that did not smell or show any vesicant properties or harm for the experiment operators.

It is noteworthy that the reaction of 4 -( $N, N$-dimethylamino $)$ 1-butanol with DMC in the presence of a base did not lead to carbonate 4 but gave the quaternary ammonium salt 5 (Scheme 2). ${ }^{44}$ Most probably, the formation of pyrrolidinium salt 5 occurs by a two-step intermolecular cyclization reaction promoted by DMC: methoxycarbonylation of the alcohol by $\mathrm{DMC}\left(\mathrm{B}_{\mathrm{Ac}} 2\right.$ mechanism), followed by a fast intramolecular alkylation to form the 1,1-dimethyl pyrrolidinium salt $5\left(\mathrm{~B}_{\mathrm{Al}}^{2}\right.$ mechanism).

This reaction is a remarkable example of cyclization via DMC chemistry, although the isolated product $\mathbf{5}$, being very stable, is not interesting for our case study and was not further investigated. However, it should be mentioned that ammonium salts such as compound $\mathbf{5}$ could be eventually used as a methylating agent under harsh reaction conditions. ${ }^{45}$

Table 1 reports on the reactivity of the half-mustard carbonates 1-3 with several nucleophiles. In a typical experiment, a mixture of half-mustard carbonate and selected nucleophiles were reacted at $180{ }^{\circ} \mathrm{C}$ in an autoclave using acetonitrile as solvent and without any base.

It was previously reported that in the absence of a base phenol does not react with carbonates derived from 2methoxyalkyl alcohol because bimolecular substitution $\left(\mathrm{B}_{\mathrm{Al}} 2\right.$
Table 1. Reactivity of Half-Mustard Carbonates with Different Nucleophiles ${ }^{a}$

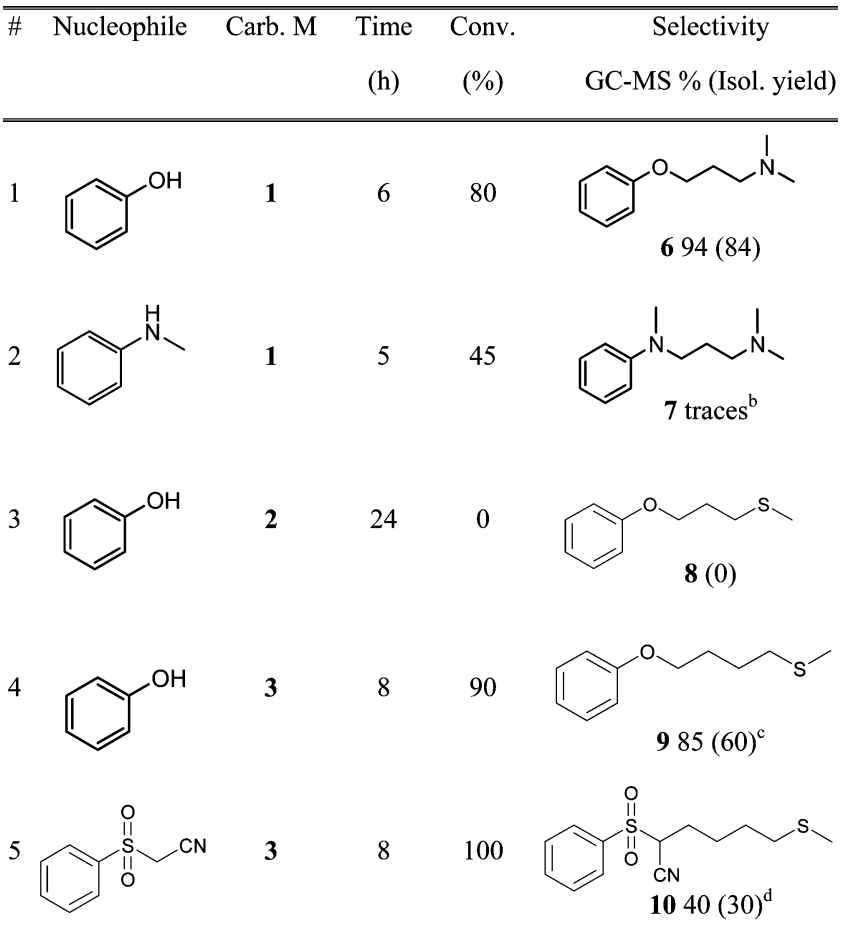

${ }^{a}$ Reaction conditions: Nucleophile:carbonate $1: 1$ molar ratio in acetonitrile at $180{ }^{\circ} \mathrm{C}$. ${ }^{b}$ GC-MS showed numerous unidentified products. ${ }^{c} \mathrm{GC}-\mathrm{MS}$ analysis showed also $13 \%$ of anisole. ${ }^{d} \mathrm{GC}-\mathrm{MS}$ analysis showed also $35 \%$ of monomethylated product and several unidentified products.

Scheme 3. Synthesis of Sulfur and Nitrogen Mustard Carbonates

$$
\begin{aligned}
& 11 \mathrm{X}=\mathrm{NMe} ; \mathrm{R}=\mathrm{Me} \quad 13 \mathrm{X}=\mathrm{S} ; \mathrm{R}=\mathrm{Me} \\
& 12 \mathrm{X}=\mathrm{NMe} ; \mathrm{R}=\mathrm{Et}
\end{aligned}
$$

mechanism) is predominant in base-promoted DAC reactions. On the contrary, half-mustard carbonates were shown to react with nucleophiles due to the anchimeric effect. ${ }^{43}$

Similarly, 3-(N,N-dimethylamino)propyl methyl carbonate $\mathbf{1}$ reacts readily with phenol under neutral conditions resulting in highly selective formation (94\%) of $N, N$-dimethyl-3-phenoxypropanamine 6 (entry 1 , Table 1 ). However, when $N$ methylaniline, a weaker nucleophile, was employed, only a modest conversion and poor selectivity toward the wanted product 7 was observed (entry 2, Table 1). Sulfur half-mustard 3-(methylthio)propyl methyl carbonate 2 did not react at all with phenol even after $24 \mathrm{~h}$ (entry 3, Table 1) under the investigated reaction conditions. On the contrary, 4(methylthio)butyl methyl carbonate 3 was shown to react with both the phenol and phenylsufonyl acetonitrile with good to moderate yield, respectively, (entries 4 and 5, Table 1). All the alkylated products have been isolated and fully characterized.

Most probably, all the above-reported alkylation reactions proceed through a cyclic intermediate aided by the anchimeric 
Table 2. Reactivity of Mustard Carbonates with Different Nucleophiles ${ }^{a}$

1<smiles>Oc1ccccc1</smiles>

11

5

100

2<smiles>Oc1ccccc1</smiles>

12<smiles>N#CCS(=O)(=O)c1ccccc1</smiles>

11

7

6<smiles>C1CCCCC1</smiles>

4<smiles>Oc1ccccc1</smiles>

13
24
100<smiles>CN(CCOc1ccccc1)CCOc1ccccc1</smiles>

$1490(76)$

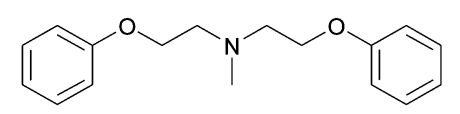

$1490(80)$<smiles>CN1CCC(C#N)(S(=O)(=O)c2ccccc2)CC1</smiles>

$15100(60)$

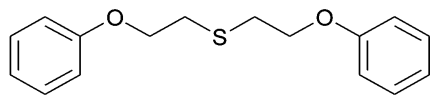

$16(0)$

${ }^{a}$ Reaction conditions: Nucleophile:carbonate $2: 1$ molar ratio in acetonitrile at $180{ }^{\circ} \mathrm{C} .{ }^{b}$ Reaction conditions: Nucleophile:carbonate $1: 1$ molar ratio in acetonitrile at $180{ }^{\circ} \mathrm{C}$.

Scheme 4. Synthesis of Substituted Piperidine 15

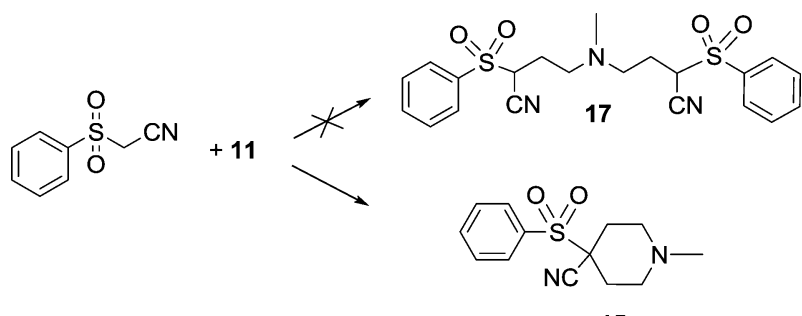

15<smiles>CC(=O)OCCN(C)C</smiles><smiles>CCOC(=O)OCCN(C)C</smiles>

Figure 2. 2-(N,N-dimethylamino)ethyl methyl carbonate 18 and 2(N,N-dimethylamino)ethyl ethyl carbonate 19.

effect of the nitrogen/sulfur atom (Scheme 2). In particular, reactions involving 3-(N,N-dimethylamino)propyl methyl carbonate $\mathbf{1}$ and 3-(methylthio)propyl methyl carbonate $\mathbf{2}$ form the 1,1-dimethylazetidinium and 1-methylthietanium fourmember cyclic intermediates, respectively (Scheme 2 ).

Results collected (entries 1-3, Table 1) seem to suggest that the 1-methylthietanium, only scarcely reported in the literature, ${ }^{46}$ is a less stable intermediate compared to 1,1 - dimethylazetidinium. ${ }^{47}$ Most probably the anchimeric effect of the sulfur mustard carbonate $\mathbf{2}$ is not strong enough to stabilize the strained four-member cyclic intermediate.

On the other hand, both mustard carbonates $\mathbf{3}$ and $\mathbf{4}$ are very reactive. As expected, five-member cyclic intermediates are less sterically strained; thus, sulfur and nitrogen anchimeric effect are strong enough to promote the alkylation reaction. Although, 4-(N,N-dimethylamino)butyl methyl carbonate 4 once formed undergoes fast intramolecular cyclization leading to the very stable quaternary ammonium salt $\mathbf{5}$ isolated as pure in quantitative yield.

Double-functionalized symmetrical mustard (iprit) carbonates were also investigated. Bis- $N, N-[(2$-alkylcarbonate $)$ ethyl]methylamine 11-12 and bis-(2-methylcarbonate)ethyl sulfide 13 were easily prepared starting from the commercially available parent alcohols (Scheme 3 ).

Table 2 reports the results collected reacting the mustard carbonates with several nucleophiles. In particular, bis- $N, N-[2-$ alkylcarbonate)ethyl]methylamines $\mathbf{1 1}$ and $\mathbf{1 2}$ react readily with phenol resulting in a double alkylation in quantitative conversion and high isolated yields (entries 1-2, Table 2).

It is noteworthy that the reaction of phenylsulfonyl acetonitrile with mustard carbonate $\mathbf{1 1}$ undergoes an intermolecular cyclization leading to the formation of a

Table 3. Kinetic First-Order Studies on Reaction of Mustard Carbonates 1, 18, and 19 with Phenol ${ }^{a}$

\begin{tabular}{|c|c|c|c|c|c|c|c|c|c|c|c|}
\hline no. & carbonate & temp $\left({ }^{\circ} \mathrm{C}\right)$ & $k\left(\mathrm{~h}^{-1}\right)$ & no. & carbonate & temp $\left({ }^{\circ} \mathrm{C}\right)$ & $k\left(\mathrm{~h}^{-1}\right)$ & no. & carbonate & temp $\left({ }^{\circ} \mathrm{C}\right)$ & $k\left(\mathrm{~h}^{-1}\right)$ \\
\hline 1 & 18 & 160 & 0.7289 & 6 & 19 & 160 & 0.3642 & 11 & 1 & 170 & 0.4167 \\
\hline 2 & 18 & 170 & 1.3046 & 7 & 19 & 170 & 0.6915 & 12 & 1 & 180 & 0.7660 \\
\hline 3 & 18 & 180 & 3.0206 & 8 & 19 & 180 & 1.3851 & 13 & 1 & 190 & 1.6032 \\
\hline 4 & 18 & 190 & 5.0622 & 9 & 19 & 190 & 2.6848 & 14 & 1 & 200 & 3.0455 \\
\hline 5 & 18 & 200 & 7.6421 & 10 & 19 & 200 & 6.9785 & 15 & 1 & 210 & 6.0873 \\
\hline
\end{tabular}

${ }^{a}$ Phenol:carbonate 1:1 molar ratio in acetonitrile in the presence of p-xylene (1 mol equiv) as internal standard. All reactions were conducted in an autoclave. 


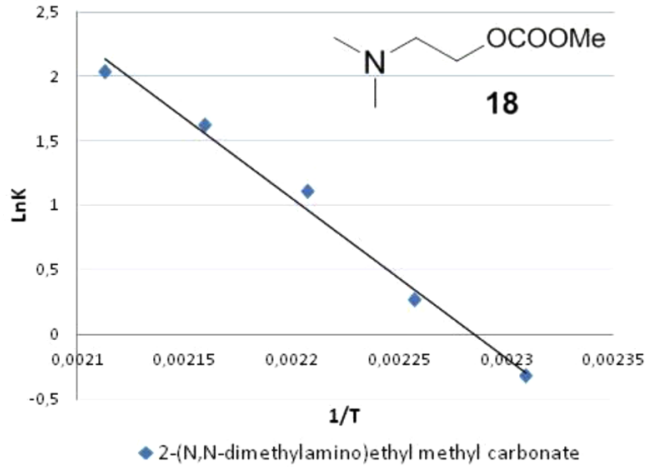

$\mathrm{Ea}=102,92 \mathrm{KJ} \mathrm{mol}^{-1}$

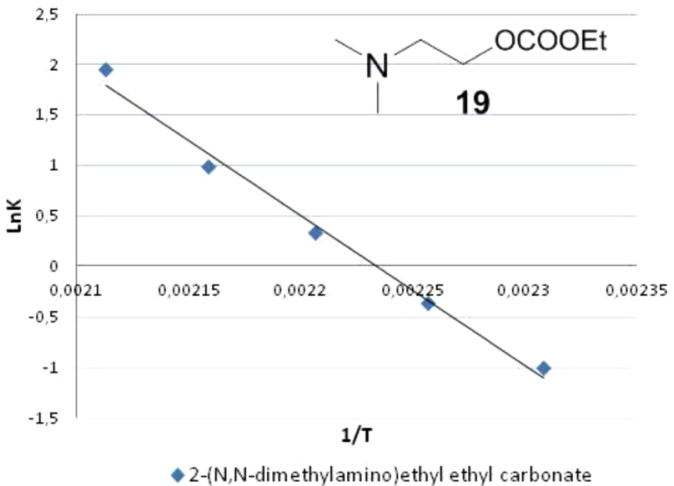

$\mathrm{Ea}=122,95 \mathrm{KJ} \mathrm{mol}^{-1}$

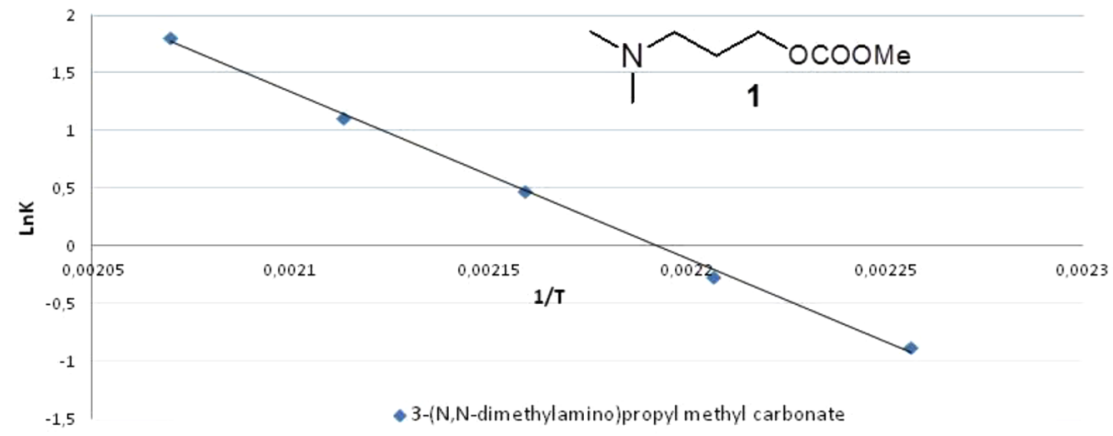

$\mathrm{Ea}=119,97 \mathrm{KJ} \mathrm{mol}^{-1}$

Figure 3. Activation energy for the reaction of phenol with mustard carbonates 1, 18, and 19.

substituted piperidine 15 (Scheme 4). This reaction was first conducted employing an excess of phenylsulfonyl acetonitrile; however, the bis-alkylated product 17 was never detected. $\mathrm{N}$ methyl-4-(phenylsulfonyl)-4-cyano-piperidine 15 resulted the main product formed according to GC-MS analysis. The reaction was then repeated employing a stoichiometric amount of phenylsulfonyl acetonitrile resulting in a high yield conversion of the substrate into the substituted piperidine isolated as pure in $60 \%$ yield by column chromatography (entry 3, Table 2). This reaction is a remarkable example of a intermolecular cyclization proceeding through a double alkylation reaction.

Conversely, bis-(2-methylcarbonate)ethyl sulfide 13 did not react with any nucleophiles even at higher temperatures, i.e., $200{ }^{\circ} \mathrm{C}$. This result may be ascribed to the steric hindrance of the reagent that was predominant on the anchimeric effect of the sulfur in this reaction conditions.

The reaction kinetics at $180{ }^{\circ} \mathrm{C}$ of simple nitrogen halfmustard compounds, i.e., 2-(N,N-dimethylamino)ethyl ethyl carbonate 19, have been recently reported. ${ }^{43}$ In this work, we report on the reaction kinetics at different temperatures for compounds 18 and 19 (Figure 2) comparing them with the newly synthetized ( $N, N$-dimethylamino)propyl methyl carbonate 1 that incorporates a propyl chain instead than an ethyl one. The related activation energy values of half-mustard carbonate 1, 18, and 19 have also been calculated.

Kinetic studies have been conducted by GC-MS analysis on the reaction of 2-(N,N-dimethylamino)ethyl ethyl carbonate 19 and phenol at different temperatures. Similar investigations were also carried out on 2-(N,N-dimethylamino)ethyl methyl carbonate 18 and 3-(N,N-dimethylamino)propyl methyl carbonate 1 .

The resulting reaction kinetics confirmed to be of the firstorder for all the case studies (Table 3, Supporting Information).

Applying the Arrhenius equation on the kinetic data collected allowed us to determine the activation energy for the reaction of phenol with the half-mustard carbonates 1, 18, and 19 (Figure 3). Among the three half-mustard carbonates, 2-(N,Ndimethylamino)ethyl methyl carbonate $\mathbf{1 8}$ has the lowest activation energy, while 2-(N,N-dimethylamino)ethyl methyl carbonate 19 has the higher. These results might be explained by carbonate 19 being the most sterically hindered leaving group and thus requiring a higher activation energy to form the cyclic three-member intermediate. However, the reaction mechanism can be also more complicated, i.e., the relative basicity of the leaving group could also play an important role. Mustard carbonate 1 showed an activation energy higher than carbonate $\mathbf{1 8}$, as the reaction intermediate is a four-member cyclic compound and lower than mustard carbonate 19 due to the fact that the methylcarbonate is a better leaving group.

Reaction kinetics of sulfur mustard carbonates were also investigated. However, these compounds were not easily detectable by GC-MS analysis, and data collected resulted difficult to interpret.

\section{CONCLUSION}

In this paper, we report on several new half-mustard and mustard carbonates. Using DMC chemistry, it was possible to 
domesticate well-known chemical weapons, i.e., mustard compounds. These compounds resulted new, unexplored, and safe molecules showing a good reactivity that might give open access to a variety of compounds previously not easily accessible.

3-(N,N-dimethylamino)propyl methyl carbonate $\mathbf{1}$ and (methylthio)butyl methyl carbonate 3 both were very reactive toward nucleophiles, meanwhile the (methylthio)propyl methyl carbonate 2 did not react at all under these reaction conditions. 4-(N,N-Dimethylamino)butyl methyl carbonate 4 was never isolated as it readily undergoes intramolecular cyclization forming a quaternary ammonium salt $\mathbf{5}$ isolated as pure in quantitative yield.

Mustard carbonates 11-13, easily synthesized as pure compounds, showed an intriguing reactivity. Nitrogen mustard carbonates 11 and 12 reacted readily with several nucleophiles leading, in the case of phenylsulfonyl acetonitrile, to a substituted piperidine by intermolecular cyclization. On the other hand, sulfur mustard carbonate $\mathbf{1 3}$ did not react with any nucleophile under the studied conditions.

It is noteworthy that in all the reported reactions the carbonate moiety acts as a green leaving group in substitution of the halogen atom.

Finally, the reaction kinetics have been also investigated for the reaction of the three different half-mustard carbonates $\mathbf{1}$, 18 , and 19 with phenol. The calculated activation energy was shown to be lower for half-mustard carbonates $\mathbf{1}$ and $\mathbf{1 8}$ bearing the methylcarbonate group. This could be due to the less sterically hindered leaving group, although a more complicated reaction mechanism cannot be excluded.

In conclusion, newly synthesized sulfur and nitrogen mustard carbonates displayed a chemical behavior and reaction kinetic similar to their parent chlorine compounds. However, mustard carbonates are green, stable, and safe compounds. Furthermore, most of these molecules are unexplored and might provide a novel strategy for the preparation of compounds previously not easily accessible.

\section{ASSOCIATED CONTENT}

\section{(5) Supporting Information}

${ }^{1} \mathrm{H}$ and ${ }^{13} \mathrm{C}$ NMR spectra and GC-MS and kinetic data. This material is available free of charge via the Internet at http:// pubs.acs.org.

\section{AUTHOR INFORMATION}

\section{Corresponding Author}

*E-mail: tundop@unive.it. Fax:+39 041234 8600. Tel:+39 041 2348642.

\section{Notes}

The authors declare no competing financial interest.

\section{REFERENCES}

(1) White, W. E.; Sobus, M. J.; Okerberg, B. C. Conformations of mustard sulfoxide and mustard sulfone. Phosphorus, Sulfur Silicon Relat. Elem. 1998, 142, 149-165.

(2) Dacre, J. C.; Goldman, M. Toxicology and pharmacology of the chemical warfare agent sulfur mustard. Pharmacol. Rev. 1996, 48, 289326.

(3) Liu, J.; Powell, K. L.; Thames, H. D.; MacLeod, M. C. Detoxication of sulfur half-mustards by nucleophilic scavengers: robust activity of thiopurines. Chem. Res. Toxicol. 2010, 23, 488-496.
(4) Wang, Q.-Q.; Begum, R. A.; Day, V. W.; Bowman-James, K. Molecular thioamide $\leftrightarrow$ iminothiolate switches for sulfur mustards. Inorg. Chem. 2012, 51, 760-762.

(5) Erdem, O. F.; Silakov, A.; Reijerse, E.; Lubitz, W.; Lennart, K.-G. S.; Huang, P.; Ott, S.; Stein, M. A model of the [FeFe] hydrogenase active site with a biologically relevant azadithiolate bridge: A spectroscopic and theoretical investigation. Angew. Chem., Int. Ed. 2011, 50, 1439-1443.

(6) Fliedel, C.; Sabbatini, A.; Braunstein, P. Synthesis of N,N'bis(thioether)-functionalized imidazolium salts: their reactivity towards $\mathrm{Ag}$ and Pd complexes and first S,CNHC,S free carbene. Dalton Trans. 2010, 39, 8820-8828.

(7) Ulmann, P. A.; Brown, A. M.; Ovchinnikov, M. V.; Mirkin, C. A.; DiPasquale, A. G.; Rheingold, A. L. Spontaneous formation of heteroligated PtII complexes with chelating hemilabile ligands. Chem.-Eur. J. 2007, 13, 4529-4534.

(8) Mai, V.; Comstock, L. R. Synthesis of an azide-bearing N-mustard analogue of S-adenosyl-L-methionine. J. Org. Chem. 2011, 76, 1031910324.

(9) Konstantinova, I.; Bukhryakov, K.; Gezentsvey, Y.; Krasavin, M. Practical method for parallel synthesis of diversely substituted 1phenylpiperazines. Lett. Org. Chem. 2011, 8, 628-630.

(10) Choy, R. P. Y.; Lau, C. P.; Kwong, F. Y. Palladium-catalyzed direct and regioselective $\mathrm{C}-\mathrm{H}$ bond functionalization/oxidative acetoxylation of indoles. J. Org. Chem. 2011, 76, 80-84.

(11) Shevchenko, N. E.; Nenajdenko, V. G.; Balenkova, E. S. Triflic anhydride-promoted cyclization of sulfides: A convenient synthesis of fused sulfur heterocycles. Synthesis 2003, 8, 1191-1200.

(12) Griesbeck, A. G.; Oelgemoeller, M.; Lex, J. Photochemistry of MTM- and MTE-esters of $\omega$-phthalimido carboxylic acids: Macrocyclization versus deprotection. J. Org. Chem. 2000, 65, 9028-9032.

(13) Fang, J.; Wallikewitz, B. H.; Gao, F.; Tu, G.; Muller, C.; Pace, G.; Friend, R. H.; Huck, T. S. Conjugated zwitterionic polyelectrolyte as the charge injection layer for high-performance polymer lightemitting diodes. J. Am. Chem. Soc. 2011, 133, 683-685.

(14) Wang, L.; Wen, Y.; Liu, J.; Zhou, J.; Li, C.; Wei, C. Promoting the formation and stabilization of human telomeric G-quadruplex DNA, inhibition of telomerase and cytotoxicity by phenanthroline derivatives. Org. Biomol. Chem. 2011, 9, 2648-2653.

(15) Block, E. Reactions of Organosulfur Compounds; Academic Press: New York, 1978.

(16) Barnes, M. C. S.; Dennison, H. J.; Flack, S. S.; Lumley, J. A.; Pang, P. S.; Spencer, K. C. Patent WO2011/27156, 2011.

(17) Moneo Ocana, V.; Santamaria Nunez, G.; Garcia Fernandez, L. F.; Galmarini, C. M.; Guillen Navarro, M. J.; Aviles Marin, P. M. Patent WO2012/62920, 2012.

(18) Laufer, S. A.; Margutti, S. Isoxazolone based inhibitors of p38 MAP kinases. J. Med. Chem. 2008, 51, 2580-2584.

(19) Goldstein, D. M.; Rueth, M. U.S. Patent US2007/219195 A1, 2007.

(20) Birch, A. M.; Simpson, I.; Stocker, A.; Whittamore, P. R. O. Patent WO2005/20987, 2005

(21) Ahn, G.; Couture, A.; Grandclaudon, P.; Ryckebusch, A.; Schifano-Faux, N.; Goossens, J.-F.; Baldeyrou, B.; Lansiaux, A. Synthesis, cytotoxicity and topoisomerase inhibition properties of multifarious aminoalkylated indeno[1,2-c] isoquinolin-5,11-diones. Med. Chem. Lett. 2011, 21, 2259-2263.

(22) Phippen, C. B.; McErlean, C. S. P. A 1,5-benzothiazepine synthesis. Tetrahedron Lett. 2011, 52, 1490-1492.

(23) Descôteaux, C.; Brasseur, K.; Leblanc, V.; Parent, S.; Asselin, É.; Bérubé, G. Design of novel tyrosine-nitrogen mustard hybrid molecules active against uterine, ovarian and breast cancer cell lines. Steroids 2012, 77, 403-412.

(24) Polavarapu, A.; Stillabower, J. A.; Stubblefield, S. G. W.; Taylor, W. M.; Baik, M.-H. The mechanism of guanine alkylation by nitrogen mustards: A computational study. J. Org. Chem. 2012, 77, 5914.

(25) Tundo, P.; Selva, M.; Perosa, A.; Memoli, S. Selective mono-Cmethylations of arylacetonitriles and arylacetates with dimethylcar- 
bonate: A mechanistic investigation. J. Org. Chem. 2002, 67, 10711077.

(26) Grego, S.; Aricò, F.; Tundo, P. Phosgene-free carbamoylation of aniline via dimethyl carbonate. Pure Appl. Chem. 2012, 84, 695-705.

(27) McElroy, C. R.; Aricò, F.; Benetollo, F.; Tundo, P. Cyclization reaction of amines with dialkyl carbonates to yield 1,3-oxazinan-2ones. Pure Appl. Chem. 2012, 84, 707-719.

(28) Tundo, P.; Anastas, P. Green Chemistry: Challenging Perspectives; Oxford University Press: Oxford, U.K., 2000.

(29) Asahi Kasei Chemicals Corporation. Patent WO2007/34669 A1, 2007.

(30) Budavari, S., Ed.; The Merck Index; Merck and Co., Inc.: Whitehouse Station, NJ, 1989.

(31) Aricò, F.; Toniolo, U.; Tundo, P. 5-Membered N-heterocyclic compounds by dimethyl carbonate chemistry. Green Chem. 2012, 14, $58-61$.

(32) Aricò, F.; Tundo, P.; Maranzana, A.; Tonachini, G. Synthesis of five-membered cyclic ethers by reaction of 1,4-diols with dimethyl carbonate. ChemSusChem 2012, 5, 1578-1586.

(33) Tundo, P.; Aricò, F.; Gauthier, G.; Rossi, L.; Rosamilia, A. E.; Bevinakatti, H. S.; Sievert, R. L.; Newman, C. P. Green synthesis of dimethyl isosorbide. ChemSusChem 2010, 3, 566-570.

(34) Tundo, P.; Aricò, F. Dimethyl carbonate as a sacrificial molecule for the synthesis of 5-membered N- and O-heterocycles. J. Chin. Chem. Soc. 2012, 59, 1375-1384.

(35) Bevinakatti, H. S.; Newman, C. P.; Ellwood, S.; Tundo, P.; Aricò, F. Patent WO2009010791 (A2), 2009.

(36) Riva, L.; Mangano, R.; Tundo, P. Patent PCT/IB2008/003409, 2008.

(37) Tundo, P.; Selva, M. The chemistry of dimethyl carbonate. Acc. Chem. Res. 2002, 35, 706-716.

(38) Rosamilia, A. E.; Aricò, F.; Tundo, P. Reaction of the ambident electrophile dimethyl carbonate with the ambident nucleophile phenylhydrazine. J. Org. Chem. 2008, 73, 1559-1562.

(39) Tundo, P.; Memoli, S.; Hérault, D.; Hill, K. Synthesis of methylethers by reaction of alcohols with dimethylcarbonate. Green Chem. 2004, 6, 609-612.

(40) Tundo, P.; Aricò, F.; Rosamilia, A. E.; Memoli, S. Synthesis of dialkyl ethers by decarboxylation of dialkyl carbonates. Green Chem. 2008, 10, 1182-1189.

(41) Tundo, P.; McElroy, C. R.; Aricò, F. Synthesis of carbamates by reaction of amines with dialkyl carbonates: influence of leaving and entering groups. Synlett 2010, 10, 1567-1571.

(42) Rosamilia, A. E.; Aricò, F.; Tundo, P. Insight into the hard-soft acid-base properties of differently substituted phenylhydrazines in reactions with dimethyl carbonate. J. Phys. Chem. B 2008, 112, 1452514529 .

(43) Aricò, F.; Chiurato, M.; Peltier, J.; Tundo, P. Sulfur and nitrogen mustard carbonate analogues. Eur. J. Org. Chem. 2012, 3223.

(44) Chiappe, C.; Sanzone, A.; Dyson, J. P. Styrene oxidation by hydrogen peroxide in ionic liquids: The role of the solvent on the competition between two Pd-catalyzed processes, oxidation and dimerization. Green Chem. 2011, 13, 1437-1441.

(45) Zafinyan, S. A.; Khachatryan, R. A.; Indzhikyan, M. H. Quaternary ammonium salts as alkylating agents in the synthesis of tertiary phosphine oxides. Russ. Chem. Bull. 1999, 48, 388-390.

(46) Benn, M. H.; Vinod Singh, K. A simple, biogenetically modeled synthesis of 4-(methylthio)butyl thiocyanate: the reaction of thiocyanate anion with S-methyl-(1,n)-epithionium ions. Can. J. Chem. 1986, 64, 940.

(47) Gibbs, M. Quaternary ammonium salts from bromopropyldialkylamines. V. Conversion of cyclic ammonium salts to linear polymers. J. Am. Chem. Soc. 1935, 57, 1137-1139. 